\title{
POTENSI BOKASHI Azolla sp. DENGAN BIOAKTIVATOR MOL REBUNG BAMBU TERHADAP PERTUMBUHAN PADI PANDANWANGI PADA FASE VEGETATIF
}

\author{
Oleh : \\ Siti Yiyis Rahmah \\ Angga Adriana Imansyah \\ Riza Trihaditia \\ Ahmad Nur Rizal \\ Rahmat Taufiq Dwi Jartmika \\ Fakultas Sains Terapan Universitas Suryakancana
}

\begin{abstract}
Abstrak
Padi Pandanwangi merupakan salah satu padi lokal dari Cianjur. Namun, untuk meminimalisir penggunaan pupuk sintetis, mengurangi dampak pencemaran lingkungan dan produksi optimal adalah pemanfaatan Azolla sp. dan mol rebung bambu sebagai bokashi. Bokashi Azolla sp. merupakan pupuk yang memiliki banyak unsur hara dan dapat meningkatkan bahan organik dalam tanah. Kandungan unsur hara diantaranya nitrogen (N) 2,55-3,95\%, fosfor (P) 0,35-0,85\%, kalium (K) 1,80-3,90\%, kalsium (Ca) 0,40-0,85\%, magnesium (Mg) 0,30-0,40\%, mangan (Mn) 0,09-0,12 dan besi (Fe) 0,20-0,30\%. Penelitian ini dilaksanakan pada Februari sampai Mei 2018 di Sreen House Fakultas Sains Terapan, menggunakan Rancangan Acak Lengkap yang terdiri dari 7 perlakuan dan 4 ulangan, yaitu K1 (Bokhasi kotoran domba 500 gram/ember), K2 (Bokashi Azolla sp. 400 gram/ember tanpa bokashi kotoran domba), A1 (Bokashi Azolla sp. 350 gram/ember), A2 (Bokashi Azolla sp. 400 gram/ember), A3 (Bokahsi Azolla sp. 450 gram/ember), A4 (Bokashi Azolla sp. 500 gram/ember) dan A5 (Bokashi Azolla sp. 550 gram/ember). Hasil uji lanjut DMRT, K2 (Bokashi Azolla sp. 400 gram/ember tanpa bokashi kotoran domba) berpengaruh terhadap tinggi tanaman, jumlah daun, jumlah anakan dan warna daun. Nilai rata-rata hasil pada saat umur 49 HST pada tinggi tanaman yaitu $133.21 \mathrm{~cm}$, jumlah daun 16.37 helai, jumlah anakan 2.12 batang dan warna daun 4.79. Namun, pada jumlah anakan umur 49 HST nilai rata-rata tertinggi terdapat pada A3 (Bokahsi Azolla sp. 450 gram/ember) yaitu 2.20 batang dan K1 (Bokashi kotoran domba 500 gram/ember) memiliki nilai rata-rata yang sama dengan K2 (Bokashi Azolla sp. 400 gram/ember tanpa bokashi kotoran domba) yaitu 2.12 batang.
\end{abstract}

Kata kunci : Padi Pandanwangi, Bokashi, Azolla sp., MOL Rebung Bambu.

\begin{abstract}
Pandanwangi rice is one of the local rice from Cianjur. However, to minimize the use of synthetic fertilizers, reducing the impact of environmental pollution and optimal production is the utilization of Azolla sp. and bamboo shoots MOL as bokashi. Bokashi Azolla sp. is a fertilizer that has many nutrients and can increases organic matter in the soil. Nutrient contents include nitrogen (N) 2.55-3.95\%, phosphorus (P) 0.35-0.85\%, potassium (K) 1.80-3.90\%, calcium (Ca) $0.40-0.85 \%$, magnesium (Mg) 0.30-0.40\%, manganese (Mn) 0.09-0.12 and iron (Fe) 0.20-0.30\%. The study was conducted from February to May 2018 at the Sreen House Applied Science Faculty, using a Completely Randomized Design consisting of 7 treatments and 4 replications, scilicet K1 (Bokhasi sheep dung 500 gram / bucket), K2 (Bokashi Azolla sp. 400 gram / bucket without bokashi sheep dung), A1 (Bokashi Azolla sp. 350 gram / bucket), A3
\end{abstract}

POTENSI BOKASHI Azolla sp. DENGAN BIOAKTIVATOR MOL REBUNG BAMBU TERHADAP PERTUMBUHAN PADI PANDANWANGI PADA FASE VEGETATIF
SITI YIYIS RAHMAH, ANGGA ADRIANA IMANSYAH, RIZA TRIHADITIA, R. TAUFIQ D. JATMIKA AHMAD NUR RIZAL 
(Bokahsi Azolla sp. 450 gram / bucket), A4 (Bokashi Azolla sp. 500 gram / bucket) and A5 (Bokashi Azolla sp. 550 gram / bucket). Further test results of DMRT, the best treatment is K2 (Bokashi Azolla sp. 400 gram / bucket without bokashi sheep dung) effect on plant height, number of leaves, number of tillers and leaf color. Average yield at the age of 49 HST at plant height that is $133.21 \mathrm{~cm}$, the number of leaves 16.37 strands, the number of tillers 2.12 stems and leaf color 4.79 . However, in the number of tillers the age of 49 HST the highest average value was in A3 (Bokahsi Azolla sp. 450 gram / bucket) ie 2.20 stems and K1 (Bokashi sheep drops of 500 grams / bucket) has the same average value as K2 (Bokashi Azolla sp. 400 gram / bucket without bokeashi sheep dung) scilicet 2.12 stems.

Keywords: Pandanwangi Rice, Bokashi, Azolla sp.,Bamboo Shoots MOL.

POTENSI BOKASHI Azolla sp. DENGAN BIOAKTIVATOR MOL REBUNG BAMBU TERHADAP PERTUMBUHAN
SITI YIYIS RAHMAH, ANGGA ADRIANA IMANSYAH, RIZA TRIHADITIA, R. TAUFIQ D. JATMIKA AHMAD NUR RIZAL 


\section{PENDAHULUAN}

Kebutuhan beras di Indonesia pada setiap tahun selalu mengalami peningkatan begitupun berbanding lurus dengan jumlah penduduknya. Sedangkan komoditas tanaman pangan padi (beras) sebagai bahan makanan utama masyarakat Indonsesia yang mencapai 255, 46 juta orang dengan laju pertumbuhan sebesar $1,31 \%$ dan tingkat konsumsi beras mencapai 124, 89 kg/kapita/tahun. Namun, prediksi tahun 2017-2019 akan mencapai 80,93 juta ton atau terus meningkat sebesar 2,68\% pada setiap tahunnya (Kementerian Pertanian, 2016).

Padi Pandanwangi merupakan salah satu padi aromatik yang tergolong javanica (bulu) dengan memiliki kualitas aroma pandan dan pulen. Selain daripada itu, termasuk komoditas prioritas tanaman pangan yang paling strategis di Kabupaten Cianjur (MP3C, 2015). Seiring perubahan peningkatan antara perubahan penduduk dan kebutuhan konsumsi beras, maka menjadi tantangan bagi petani dengan mencari pilihan teknologi budidaya yang baik untuk mampu mencukupi kebutuhan pangan dengan kualitas baik dan menyehatkan serta tidak berdampak terhadap kerusakan lingkungan yaitu mengembalikan kesuburan tanah dengan meningkatkan kandungan bahan organik (Nurrahma, 2012).

Teknologi budidaya organik dengan menggunakan pupuk dan pestisida alami menjadi solusi untuk menghasilkan produksi yang ramah lingkungan dan berkelanjutan dibandingkan menggunakan secara sintetis dengan berdampak terhadap degradasi tanah baik secara biologis, fisik dan kimia, dan resisten hama serta kesehatan manusia baik secara langsung ataupun tidak langsung. Oleh karena itu, maka tahun 2000-an dibentuk sistem pertanian berkelanjutan dengan menerapkan pertanian organik (Hartanto, 2013; Rusco et al., 2009). Pertanian organik merupakan pemanfaatan limbah sekitar baik dari tanaman, hewan atau limbah lainnya untuk mengembalikan semua jenis bahan organik agar meningkatkan kesuburan tanah, memperbaiki struktur tanah, ramah lingkungan dan sehat (Suwantoro, 2008).

Salah satu bahan produksi pupuk organik yang telah dilakukan pada tanaman padi yaitu kompos Azolla sp. dengan dosis 6 ton/ha memberikan hasil produksi gabah sebesar 8,67 ton/ha dengan persentase gabah isi 89,63\% (Kustiono et al,. 2012). Para petani sering menganggap Azolla sp. sebagai gulma yang tidak bermanfaat sehingga selalu disingkirkan dengan ditumpukkan dan dibuang begitu saja. Padahal, di sisi lain dapat dimanfaatkan sebagai pupuk tanaman padi di sawah yang dapat menekan penggunaan pupuk urea hingga $65 \mathrm{~kg} / \mathrm{ha}$ (Lumpkin dan Plucknett, 1982 dalam Syam, 2015).

Dalam pemupukan, MOL rebung bambu dapat dimanfaatkan sebagai bioaktivator bahan organik atau pengomposan. Selain daripada itu, MOL rebung bambu merupakan limbah rumah tangga yang memiliki unsur hara dan mengandung hormon untuk memacu pertumbuhan tanaman (Mardhiastuti, 2015). Pada produksi fase generatif agar menghasilkan panen optimal merupakan berawal dari persiapan fase vegetatif dengan menggunakan teknologi budidaya yang baik (Nurrahma, 2012). Oleh karena itu, maka dilakukan penelitian pembuatan bokashi Azolla sp. dengan bioaktivator MOL rebung bambu terhadap pertumbuhan padi pandanwangi pada fase vegetatif dengan memanfaatkan sumber daya lokal dalam perkembangan teknologi pertanian secara sederhana dan ramah lingkungan.

Pada penelian ini bertujuan agar mengetahui cara pemanfaatan sumber daya lokal sebagai bokashi dan kotoran domba yang berfungsi untuk meningkatkan kesuburan tanah serta pengaruh pertumbuhan padi Pandanwangi pada fase vegetatif. Selain daripada itu, penelitian ini bermanfaat
POTENSI BOKASHI Azolla sp. DENGAN BIOAKTIVATOR MOL REBUNG BAMBU TERHADAP PERTUMBUHAN PADI PANDANWANGI PADA FASE VEGETATIF 
sebagai ilmu teknologi pertanian dalam pemanfaatan sumber daya lokal dan untuk meminimalisir penggunaan pupuk sintetis.

\section{METODELOGI PENELITIAN}

\section{Waktu dan Tempat Penelitian}

Penelitian ini telah dilakukan pada Februari - Mei 2018 dan bertempat di Sreen House Fakultas Sains Terapan Universitas Suryakancana Cianjur.

\section{Bahan dan Alat}

Bahan yang digunakan untuk penelitian ini adalah benih padi Pandanwangi 448 biji (Mitra Tani Parahyangan), rebung bambu $2 \mathrm{~kg}$, pelapah pisang $1 \mathrm{~kg}$, dedak $4 \mathrm{~kg}$, Azolla sp. $20 \mathrm{~kg}$ (Pertanian Gasol), air kelapa 2 liter, air cucian beras 3 liter, pupuk kandang domba $20 \mathrm{~kg}$, gula merah 500 gram, EM4 $200 \mathrm{ml}$, garam $1 \mathrm{sdm}$, air, 470,4 gram serbuk cangkang telur, sekam dan tanah (Lahan Pak H. Usman).

Adapun alat yang digunakan adalah pisau, talenan, ember, lesung, lumpang, jerigen, botol plastik, selang, gentong, autoclave, kompor gas, kain, baki, gayung, gembor, saringan, tali plastik, lakban, label pengamatan, stik es krim, Bagan Warna Daun (BWD), timbangan, alat tulis dan kamera.

\section{Metode Penelitian}

Pembuatan MOL Rebung Bambu dan Bokashi Azolla sp.

\section{MOL Rebung Bambu}

Langkah-langkah pembuatan

MOL rebung bambu yaitu :

1) Talenan dan golok disediakan, rebung bambu dicacah kemudian dimasukkan ke dalam lesung batu dan ditumbuk hingga halus. Setelah halus dimasukkan ke ember besar.

2) Pelepah pisang dicacah agar mudah mengalami terurai.

3) Setelah itu, dimasukkan langsung ke dalam ember besar dan beserta air cucian beras dan air kelapa.

4) Setelah semua bahan dimasukkan ke dalam ember besar kemudian diaduk hingga rata dan pindahkan ke dalam jerigen agar difermentasi secara anaerob selama 20 hari serta pasang botol dan selang.

5) Setelah 20 hari difermentasi, MOL rebung bambu disaring untuk memisahkan ampasnya.

\section{Pembuatan Bokashi Azolla sp.}

Langkah-langkah pembuatan bokashi Azolla sp. yaitu :

1) Tanaman Azolla sp. disediakan dan dibersihkan hingga air dan kotoran tanah hilang. Kemudian tanaman Azolla sp yang bersih ditiriskan agar tidak banyak memiliki kandungan air.

2) Gula merah dicacah kecil dan kemudian dilarutkan dengan air hingga menjadi larutan gula.

3) Setelah itu, Azolla sp., dedak, MOL rebung bambu dan larutan gula merah dimasukkan ke gentong dan diaduk hingga rata.

4) Adonan bokashi Azolla sp. difermentasi secara anaerob selama 14 hari (Mujayyanah, 2009).

5) Setelah difermentasi, maka bokashi Azolla sp. siap digunakan untuk media tanam.

\section{Budidaya Padi Pandanwangi}

Budidaya tanaman padi Pandanwangi lokal Cianjur menurut prosedur SOP tidak berbeda jauh dengan budidaya tanaman padi yang lainnya. Tahap budidaya tanaman padi Pandanwangi menurut MP3C (2015) adalah sebagai berikut :

\section{a.Pemilihan Benih}

a) Benih yang digunakan adalah benih sebar yang hasil seleksi petani penangkar.

b) Sebelum disemai, benih terdahulu disortasi dengan larutan garam dapur 4\% untuk memisahkan gabah atau benih yang hampa dan tidak bernas. Benih yang bernas akan tenggelam ketika di larutan garam sedangkan yang tidak bernas maka akan mengapung.

c) Kemudian benih direndam selama 24 jam dan di peram selama 48 jam dan 
setiap 12 jam dilakukan penyiraman dan pembalikan. Benih siap disemai setelah keluar bakal akar sepanjang 0,5-1 cm.

d) Sebelum benih disemai, tanah di masukkan ke dalam baki besar dan tanah diberikan air agar melumpur dan lembab. Kemudian dilakukan pembuatan garis-garis agar rapi dengan sesuai besarnya baki.

e) Bibit dipindah tanamkan setelah berumur 10 hari (Amin, 2015).

\section{b. Pembuatan Media Tanaman}

a) Tanah disiapkan, masukan bokashi kotoran domba sebanyak 500 gram/ember pada setiap perlakuan terkecuali $\mathrm{K} 2$.

b) Bokashi Azolla sp. dimasukkan dan sesuai dengan perlakuan yang telah ditentukan.

c) Setelah itu, media tanah di siram air dan di diamkan selama 7 hari.

\section{c. Penanaman}

a) Setelah 10 hari, bibit dipindahkan ke media tanam yang di ember (Amin, 2015).

b) Setiap 1 ember, jumlah bibit yang ditanam yaitu 6 dan setiap lubang tanam terdiri 2 bibit tanaman serta kedalaman tanam yaitu $3 \mathrm{~cm}$.

\section{d. Pemupukan}

a) Pemupukan yaitu dilakukan pada waktu 7 hari sebelum tanam dan langsung di dalam media tanam dengan menggunakan bokashi kotoran domba 500 gram/ember terkecuali perlakuan K2 serta bokashi Azolla sp. yang sesuai dengan perlakuan.

b) Pada perawatan hanya penyiraman air dengan waktu pengaplikasiannya pagi dan sore.

\section{e. Pengendalian Organisme \\ Pengganggu Tanaman (OPT)}

a) Pengendalian OPT yaitu dilakukan secara fisik seperti gulma dengan cara dicabut.

b) Pengendalian seperti hama dilakukan dengan secara fisik seperti diambil dan di masukkan ke dalam botol dan penyakit maka dilakukan dengan

\section{Rancangan Penelitian}

Rancangan penelitian ini telah dilakukan secara eksperimental menggunakan Rancangan Acak Lengkap (RAL) non faktorial dengan 7 perlakuan 4 kali ulangan adalah sebagai berikut :

1. K1 : Bokashi kotoran domba 500 gram/ember.

2. K2 : Bokashi Azolla sp. $400 \mathrm{gram} / \mathrm{ember}$ tanpa bokashi kotoran domba.

3. A1 : Bokashi Azolla sp. 350 gram/ember + Bokashi kotoran domba 500 gram/ember.

4. A2 : Bokashi Azolla sp. 400 gram/ember + Bokashi kotoran domba 500 gram/ember.

5. A3 : Bokashi Azolla sp. 450 gram/ember + Bokashi kotoran domba 500 gram/ember.

6. A4 : Bokashi Azolla sp. 500 gram/ember + Bokashi kotoran domba 500 gram/ember.

7. A5 : Bokashi Azolla sp. 550 gram/ember + Bokashi kotoran domba 500 gram/ember.

\section{Teknik Pengumpulan Data}

Teknik pengumpulan data yang telah dilakukan 21-49 HST dengan mengamati 4 parameter diantaranya adalah sebagai berikut:

1. Tinggi tanaman (cm) yaitu dengan menggunakan meteran sebagai alat ukur. Pada pengukuran ini dilakukan di mulai dari pangkal batang sampai ujung daun tanaman tertinggi.

2.Jumlah daun (helai) dihitung secara manual keseluruhan daun yang tumbuh pada setiap unit batang tanaman/lubang tanam.

3.Jumlah anakan (batang) yaitu dihitung secara manual dengan menghitung keseluruham jumlah anakan yang tumbuh pada setiap unit tanaman/lubang tanam.

4. Warna daun yaitu dengan menggunakan alat Bagan Warna Daun (BWD). Pengamatan ini diambil dari tanaman 
yang paling tertinggi dan daun tersebut diamati $\pm 5 \mathrm{~cm}$ sebelum dibagian paling ujung. Dalam setiap bagan warna memiliki 4 warna daun dan skala penilaian yaitu 2-5.

Waktu pengamatan dilakukan pada umur padi Padanwangi 21 kemudian seminggu sekali sampai 49 HST. Pada pengamatan tinggi tanaman $(\mathrm{cm})$, jumlah daun (helai) dan warna daun diamati dari umur 21-49 HST sampai mendapatkan 5 data sedangkan jumlah anakan (batang) umur 35-49 HST sampai 3 data. Setiap 1 ember terdapat 6 bibit tanaman sehingga pada 28 ember membutuhkan 168 bibit tanaman.

\section{Teknik Analisis Data}

Data yang diperoleh dari hasil pengamatan setelah perlakuan sampai masa vegetatif kemudian diolah dan dianalisis menggunakan komputer dengan bantuan software aplikasi pengolahan data Sidik Ragam atau Analisys Of Variance (ANOVA) uji nilai P-Value yang dibandingkan dengan taraf $\alpha 5 \%$, kemudian untuk faktor perlakuan yang berpengaruh dilakukan dengan uji lanjut atau Duncan Multiple Range Test (DMRT) pada taraf $\alpha 5 \%$ menggunakan software SPSS.

\section{HASIL DAN PEMBAHASAN}

\section{Tinggi Tanaman (cm)}

Pada saat padi Pandanwangi berumur 21-49 HST, dari hasil uji ANOVA yang telah dilakukan bahwa tinggi tanaman memberikan hasil signifikan karena $\mathrm{P}$ value atau 0,000 lebih kecil dari $\alpha 0.05$ (Lampiran 6). Oleh karena itu, perlu dilakukan uji beda nyata dengan menggunakan uji lanjut DMRT.

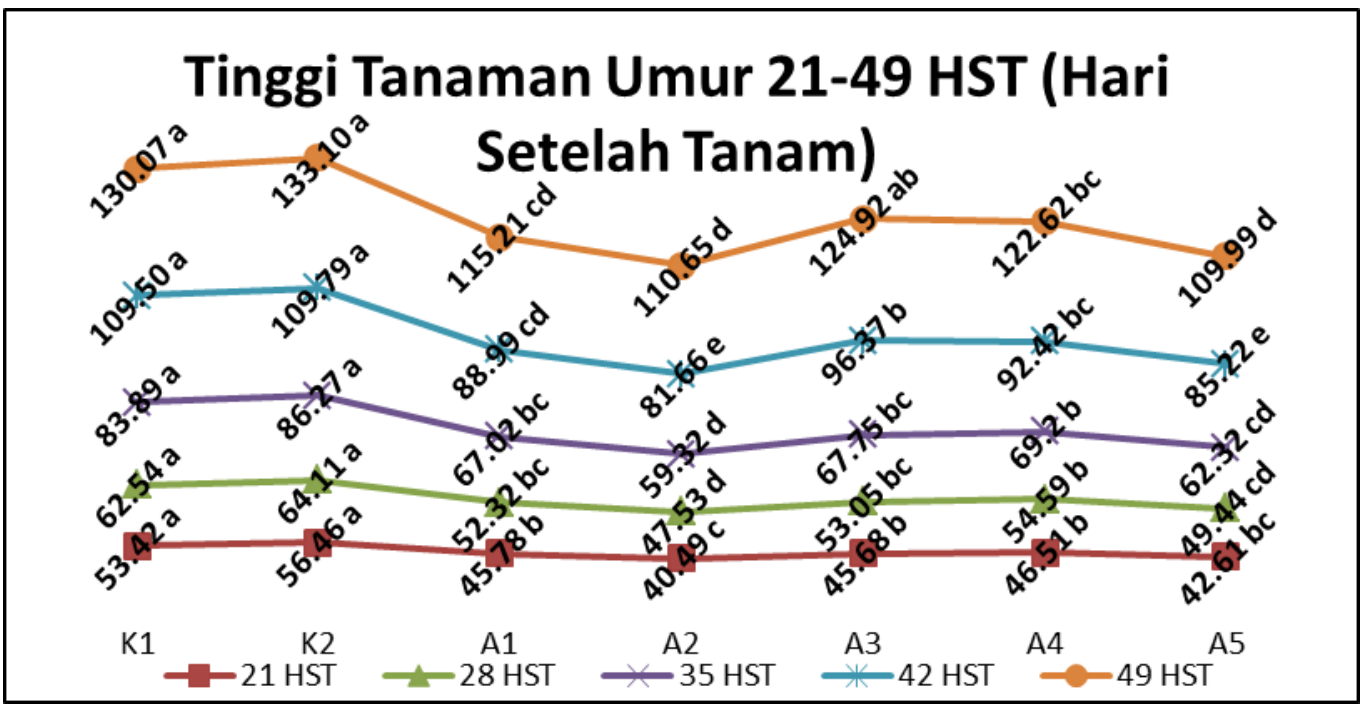

Gambar 1. Grafik uji lanjut DMRT tinggi tanaman (cm) umur 21-49 HST.

Keterangan :

1. Angka-angka yang diikuti huruf berbeda menunjukkan berbeda nyata berdasarkan Uji Duncan Multiple Range Test (DMRT) pada taraf $\alpha 5 \%$ atau 0.05 .

2. K1 (Bokhasi kotoran domba 500 gram/ember), K2 (Bokashi Azolla sp. 400 gram/ember tanpa bokashi kotoran domba), A1 (Bokashi Azolla sp. 350 gram/ember + Bokhasi kotoran domba 500 gram/ember), A2 (Bokashi Aqolla sp. 400 gram/ember + Bokhasi kotoran domba 500 gram/ember), A3 (Bokahsi Azolla sp. 450 gram/ember + Bokhasi kotoran domba 500 gram/ember), A4 (Bokashi Azolla sp. 500 gram/ember + Bokhasi kotoran domba 500 gram/ember) dan A5 (Bokashi Azolla sp. 550 gram/ember + Bokhasi kotoran domba 500 gram/ember).

Dari hasil uji lanjut Duncan Multiple Range Test (DMRT), bahwa rata-rata nilai tinggi tanaman pada umur 21-49 HST pada perlakuan K2 dan K1 tidak berbeda
POTENSI BOKASHI Azolla sp. DENGAN BIOAKTIVATOR MOL REBUNG BAMBU TERHADAP PERTUMBUHAN PADI PANDANWANGI PADA FASE VEGETATIF 
nyata diduga karena adanya kandungan nitrogen (N) yang tinggi meskipun memiliki konsentrasi dan perlakuan berbeda-beda. Namun, hasil nilai rata-rata yang terbaik adalah $\mathrm{K} 2$ karena kandungan nitrogennya $(\mathrm{N})$ sangat tinggi yaitu 2,553,95\% sedangkan K1 yaitu 0,65\% (Akhda, 2009). Oleh karena itu, pada saat fase vegetatif dengan adanya ketersediaan nitrogen $(N)$ sangat bermanfaat untuk pertumbuhan seperti akar, batang dan daun (Budiyanto dan Isnawan, 2014). Pertumbuhan terjadi oleh suatu proses pembelahan sel (peningkatan jumlah) dan pertambahan sel (peningkatan ukuran) tetapi secara irrevesibel atau tidak dapat kembali lagi serta proses pertumbuhan tinggi tanaman tidak hanya dipengaruhi oleh ketersediaan unsur hara makro seperti nitrogen $(\mathrm{N})$ tetapi fosfor $(\mathrm{P})$, kalium $(\mathrm{K})$, kalsium $(\mathrm{Ca})$ dan magnesium $(\mathrm{Mg})$ pun dibutuhkan. Selain daripada itu, unsur hara mikro pun tetap dibutuhkan walaupun sedikit seperti mangan (Mn), besi $(\mathrm{Fe})$, seng $(\mathrm{Zn})$ dan tembaga $(\mathrm{Cu})$ karena berperan sebagai katalisator dalam proses sintetis protein dan pembentukan klorofil (Salibury dan Ross, 1995).

Pada saat umur 21-28 HST bahwa perlakuan K2 dan K1 pertumbuhan tanaman padi Pandanwangi terjadi secara fase logaritmik yang secara sejalan dengan waktu bertambahnya ukuran meskipun laju pertumbuhan lambat tetapi pertumbuhan terus meningkat karena adanya meristem yang menghasilkan sel baru kemudian membesar dan berdiferensiasi. Sedangkan umur 35-49 HST mengalami kenaikan pertumbuhan yaitu fase linear dengan pertambahan ukuran berlangsung secara konstan yang disebabkan oleh aktivitas meristem apikal (Salisbury dan Ross, 1995). Selain daripada itu, penggunaan bokashi Azolla sp. dapat meningkatkan pertumbuhan karena ketersediaan bahan organik, unsur hara dan Azotobater sp. dalam MOL rebung bambu sebagai bioaktivator yang dapat mendekomposisi bahan organik serta menghasilkan hormon giberelin, sitokinin, dan asam indol asetat sehingga pemanfaatannya dapat untuk memacu pertumbuhan akar (Lasrin, 1997 dalam Gunawan, 2011).

Hormon giberelin berperan untuk mendorong perkembangan biji dan kuncup, merangsang pertumbuhan dan perkembangan akar, batang maupun daun (Dewi, 2008), sitokinan berperan untuk berdiferensiasi pada jaringan meristem pucuk dan akar, menstimulus sintesis protein dan menginduksi sintesis, pembentukan daun, pemanjangan kloroplas dan menghambat senesen (Karjadi dan Buchory, 2007) dan auksin berperan untuk mempercepat proses pertumbuhan seperti pemanjangan sel, menginduksi pembelahan sel dan berdiferensiasi sel, mempercepat perkecambahan, terhambatnya pembentukan pucuk aksiler, menghambatnya proses absisi dan membantu proses pembentukan buah serta pemasakan buah (Karjadi dan Buchory, 2007;Manik, 2011).

Pada saat umur 21-42 HST, perlakuan K2 dan berbeda nyata dengan perlakuan lainnya karena diduga bahwa perlakuan A1-A5 ketika bokashi Azolla sp. dan bokashi kotoran domba dikombinasikan maka pertumbuhan tanaman padi Pandanwangi menjadi lambat diduga karena zat asam organik terlalu banyak yang dihasilkan oleh bakteri pelarut fosfat seperti Bacillus polymyxa, Bacillus megatherium Pseudomonas striata, Thiobacillus sp. dan fungi salah satunya Aspergillus niger. Bakteri tersebut selain mengeluarkan enzim fosfatase tetapi dapat mengeluarkan asam-asam organik diantaranya asam suksinat, tartarat, sitrat glutaman, format, asetat propionate, laktonat dan furmarete (Rao,1994). Sedangkan bakteri pelarut kalium diantaranya Pseudomonas, Bacillus mucilaginosus dan Bacillus edaphicus mengeluarkan asam tartarat dan oksalat (Sheng dan He, 2006 ; Liu et al.,2006).

Kandungan fosfat $(\mathrm{P})$ dan kalium

(K) organik tidak dapat langsung digunakan oleh tanaman karena perlu ditransformasi terlebih dahulu menjadi bentuk anorganik yang melalui proses mineralisasi dan dikatalis oleh enzim 
tanah fosfatase karena dengan terlalu banyaknya zat asam organik pertumbuhan tinggi tanaman terjadi secara fase logaritmik yang pertumbuhan selnya lambat. MOL rebung bambu memiliki $\mathrm{pH}$ antara 5,4-5,7 (Batara, 2015) dan bokashi kotoran domba adalah 4,81 (Simamora et al.,2016). Pada $\mathrm{pH}$ MOL mengalami penurunan karena mikroorganisme sedang menguraikan bahan-bahan organik (Iqbal, 2008 dalam Batara, 2015).

Penurunan $\mathrm{pH}$ MOL terjadi pada hari ke-7 setelah itu $\mathrm{pH}$ cenderung stabil dan waktu fermentasi terbaik dapat diperoleh populasi mikoorganisme yang optimum adalah 7-14 hari karena semakin lama waktu fermentasi berlangsung maka tingkat dekomposisi akan berlanjut dan kondisi $\mathrm{pH}$ menjadi lebih rendah serta berdampak terhadap keracunan $\mathrm{Fe}^{2+}$ (Suhastyo, 2011). Pada saat fermentasi MOL rebung bambu, mikroorganisme beraktivitas mengeluarkan gas $\mathrm{CO}_{2}$ yang berdasarkan hasil dari pernapasan anaerob. Setelah itu, $\mathrm{CO}_{2}$ dilepaskan dengan membentuk senyawa asam karbonat $\left(\mathrm{H}_{2} \mathrm{CO}_{3}\right)$ yang mudah terurai menjadi ion-ion $\mathrm{H}^{+}$dan $\mathrm{CO}^{3-}$. Semakin lama waktu fermentasi maka dekomposisi bahan organik akan semakin lama dan $\mathrm{pH}$ menjadi rendah akibat peningkatan konsentrasi ion-ion $\mathrm{H}^{+}$sehingga akan menentukan keasaman MOL tersebut (Dwijoseputro, 2010)

Pada umur 49 HST bahwa K2 dan K1 menjadi tidak berbeda nyata dengan A1-A5 diduga bahwa zat asam organik semakin berkurang sehingga perlakuan tersebut mengalami fase linear karena aktivitas meristem apikal semakin konstan dan pertambahan tinggi tanaman terjadi karena adanya pembelahan dan pemanjangan sel (Gardner et al.,1991 dalam Buntoro et al, 2014). Selain daripada itu, diduga adanya pengaruh dari MOL rebung bambu yang dapat meningkatkan kesuburan tanah dan unsur hara yang tersedia. MOL rebung bambu memiliki kandungan bakteri Azotobacter sp., bakteri pelarut fosfat dan bakteri pelarut kalium sehingga dapat mempercepat penguraian dengan menghasilkan pupuk yang berkualitas tinggi (Mardhiastuti, 2015 ; Setyorini et al.,2006).

\section{Jumlah Daun (Helai)}

Pada saat padi Pandanwangi berumur 21-49 HST, dari hasil uji ANOVA yang telah dilakukan bahwa jumlah daun (helai) memberikan hasil signifikan karena $\mathrm{P}$ value atau 0,000 lebih kecil dari $\propto 0.05$ (Lampiran 6). Oleh karena itu, perlu dilakukan uji beda nyata dengan menggunakan uji lanjut DMRT.
POTENSI BOKASHI Azolla sp. DENGAN BIOAKTIVATOR MOL REBUNG BAMBU TERHADAP PERTUMBUHAN PADI PANDANWANGI PADA FASE VEGETATIF 


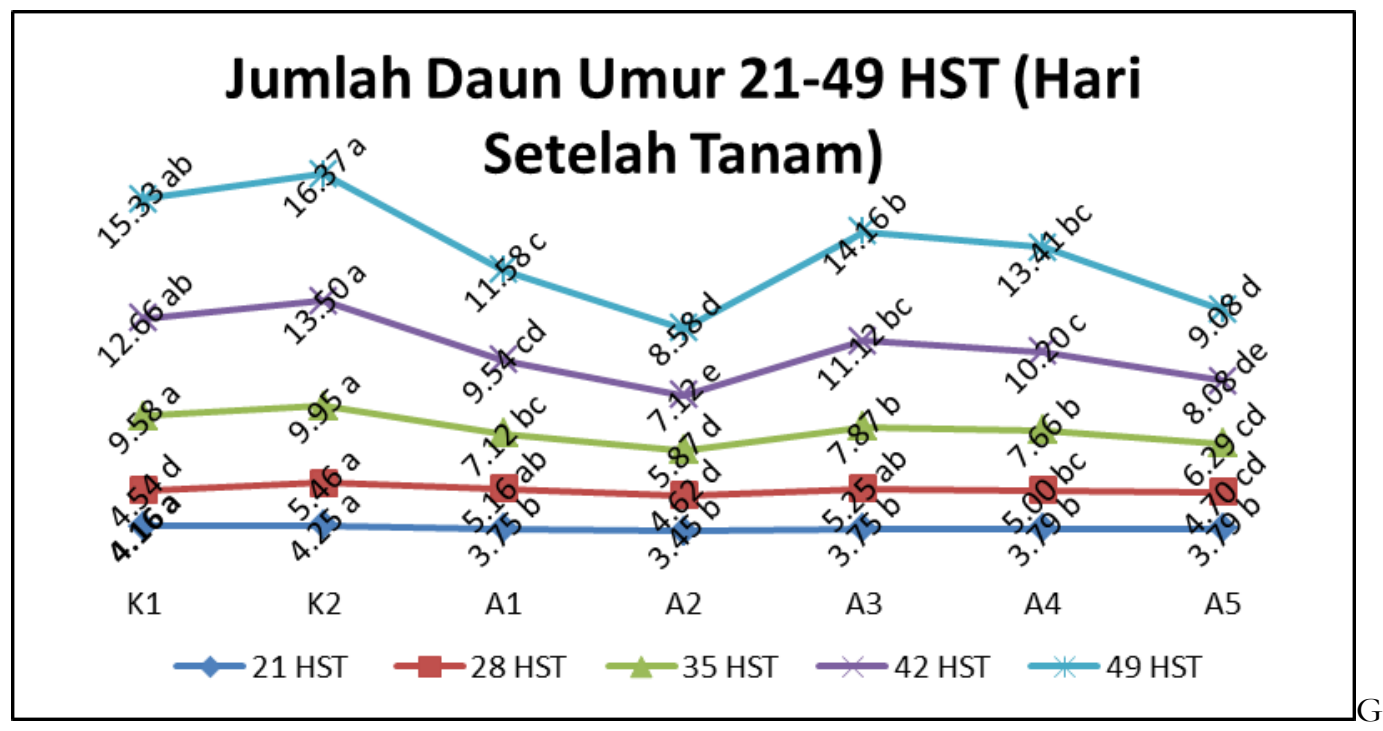

ambar 2. Grafik uji lanjut DMRT jumlah daun (helai) umur 28-49 HST.

Keterangan :

1. Angka-angka yang diikuti huruf berbeda menunjukkan berbeda nyata berdasarkan Uji Duncan Multiple Range Test (DMRT) pada taraf $\alpha 5 \%$ atau 0.05 .

2. K1 (Bokhasi kotoran domba 500 gram/ember), K2 (Bokashi Azolla sp. 400 gram/ember tanpa bokashi kotoran domba), A1 (Bokashi Azolla sp. 350 gram/ember + Bokhasi kotoran domba 500 gram/ember), A2 (Bokashi Azolla sp. 400 gram/ember + Bokhasi kotoran domba 500 gram/ember), A3 (Bokahsi Azolla sp. 450 gram/ember + Bokhasi kotoran domba 500 gram/ember), A4 (Bokashi Azolla sp. 500 gram/ember + Bokhasi kotoran domba 500 gram/ember) dan A5 (Bokashi Azolla sp. 550 gram/ember + Bokhasi kotoran domba 500 gram/ember).

Dari hasil uji lanjut Duncan Multiple Range Test (DMRT), bahwa rata-rata jumlah daun pada umur 21, 35, 42 dan 49 HST pada perlakuan K2 dan K1 tidak berbeda nyata diduga karena adanya kandungan nitrogen $(\mathrm{N})$ yang tinggi terhadap perlakuan K2 sehingga dapat merangsang pertumbuhan daun. Dalam merangsang pertumbuhan daun secara cepat yaitu ketersediaan unsur nitrogen (N) yang tinggi karena yang menyebabkan daun dan batang berwarna hijau adalah nitrogen $(\mathrm{N})$ sebagai bahan pembentuk klorofil (Dwidjoseputro, 1992 dalam Guntoro, 2017).

Jumlah daun merupakan sangat berperan dalam menangkap cahaya dan sebagai tempat berlangsungnya proses fotosintesis. Selain daripada itu, perkembangan jumlah daun akan mempengaruhi perkembangan tanaman dan banyaknya daun akan semakin banyak cahaya yang ditangkap sehingga proses fotosintesis pun meningkat (Buntoro et al., 2014). Selain daripada itu, jumlah daun dapat dipengaruhi oleh sitokinin yang terdapat pada kandungan bakteri Azotobacter sp. karena untuk pertumbuhan normal dan berdiferensiasi (Driyani, 2015).

Pada umur 28 HST K2 berbeda nyata dengan $\mathrm{K} 1$ diduga karena selain adanya ketersediaan nitrogen $(\mathrm{N})$ dan kalium (K) bahwa pertumbuhan K1 memiliki pertumbuhan fase logaritmik yang secara sejalan dengan waktu bertambahnya ukuran meskipun laju pertumbuhan lambat tetapi pertumbuhan terus meningkat karena adanya meristem dengan menghasilkan sel baru kemudian membesar dan berdiferensiasi yang dipengaruhi oleh unsur nitrogen serta kalium (K). Unsur nitrogen $(\mathrm{N})$ dan kalium (K) merupakan penyusun 
komponen penting dalam organ tanaman, sebagai unsur yang terlibat dalam proses fotosintesis, unsur sel tanaman, penyusun klorofil dan senyawa organik lainnya (Syekfani, 1997 dalam Tamrin, 2005).

Perlakuan K2 dan K1 pada saat umur 21 dan 35 HST berbeda nyata dengan perlakuan lainnya, diduga bahwa perlakuan A1-A5 bahwa ketika bokashi Azolla sp. dan bokashi kotoran domba dikombinasikan terdapat zat asam organik terlalu banyak diantaranya asam suksinat, tartarat, sitrat glutaman, format, asetat propionate, laktonat, furmarete, tartarat dan oksalat. Yang dihasilkan oleh bakteri fosfat $(\mathrm{P})$ dan kalium $(\mathrm{K})$. Oleh karena itu, zat pertumbuhan lambat pun terjadi pada parameter tinggi tanaman karena jumlah daun merupakan peningakatan dari pertumbuhan tinggi tanaman dan sangat berpengaruh untuk laju pertumbuhan fase vegetatif yang cepat karena asam organik tersebut tidak dapat langsung digunakan oleh tanaman karena perlu ditransformasi terlebih dahulu menjadi bentuk anorganik yang melalui proses mineralisasi dan dikatalis oleh enzim tanah fosfatase dan kalium (Nugroho, 2005).

Pada saat umur 28 dan 42 HST bahwa K2 dan K1 tidak berbeda nyata dengan perlakuan lainnya, diduga bahwa kombinasi bokashi Arolla sp. dan bokashi kotoran domba dikombinasikan bahwa zat asam organik terlalu banyak yang dihasilkan oleh bakteri pelarut fosfat dan kalium karena pada saat MOL rebung bambu difermentasi mikroorganisme tersebut beraktivitas mengeluarkan gas $\mathrm{CO}_{2}$ yang berdasarkan hasil dari pernapasan anaerob. Setelah itu, $\mathrm{CO}_{2}$ dilepaskan dengan membentuk senyawa asam karbonat $\left(\mathrm{H}_{2} \mathrm{CO}_{3}\right)$ yang mudah terurai menjadi ion-ion $\mathrm{H}^{+}$dan $\mathrm{CO}^{3-}$. Semakin lama waktu fermentasi maka dekomposisi bahan organik akan semakin lama dan $\mathrm{pH}$ menjadi rendah akibat peningkatan konsentrasi ion-ion $\mathrm{H}^{+}$. Pada saat umur 28 , pertumbuhan tanaman terjadi secara fase logaritmik yang secara sejalan dengan waktu bertambahnya ukuran meskipun laju pertumbuhan lambat tetapi pertumbuhan terus meningkat karena adanya meristem yang menghasilkan sel baru kemudian membesar dan berdiferensiasi. Selama proses dekomposisi terjadi pembebasan unsur hara dari senyawa-senyawa organik atau asam organik menjadi senyawa anorganik yang tersedia bagi tanaman sehingga selama pengomposan total asam meningkat dan $\mathrm{pH}$ menurun (Syaifullah, 2016).

Pada saat umur 42 HST, tanaman terjadi secara fase linear karena aktivitas meristem apikal semakin konstan dan pertambahan jumlah daun terjadi karena adanya pembelahan dan pemanjangan sel sehingga pertumbuhan tanaman pada saat vegetatif fotosintat akan diakumulasikan pada organ daun, batang dan anakan (Sitompul dan Guritno, 1995 dalam Khairunisa, 2015). Namun, pada saat umur 49 HST tidak berbeda nyata dengan perlakuan A4, A3 dan A1 diduga bahwa kombinasi bokashi Azolla sp. dan bokashi kotoran domba zat asam organik semakin berkurang. Oleh karena itu, pertumbuhan tersebut terjadi secara fase linear karena aktivitas meristem apikal semakin konstan dan pertambahan jumlah daun terjadi karena adanya pembelahan dan pemanjangan sel sehingga akar dan daun ditentukan oleh ketersediaan nitrogen $(\mathrm{N})$ di dalam tanah karena erat kaitannya dengan akar yang digunakan untuk proses pembelahan sel dan pembesaran sel serta akhirnya dipergunakan sebagai proses pembentukan akar. Apabila konsentrasi nitrogen (N) lebih tinggi maka pembentukan daun baru pada fase vegetatif sangat pesat (Tamrin, 2005). Selain daripada itu, Unsur hara fosfat (P) yang penting sebagai sumber energi dalam proses fotosintesis (Dwijoseputro, 1978).

\section{Jumlah Anakan (Batang)}

Pada saat padi Pandanwangi berumur 35-49 HST, dari hasil uji ANOVA yang telah dilakukan bahwa jumlah anakan (batang) memberikan hasil signifikan karena $\mathrm{P}$ value atau 0,000 lebih kecil dari $\alpha 0.05$ (lampiran 6). Oleh karena itu, perlu dilakukan uji beda nyata dengan menggunakan uji lanjut DMRT. 


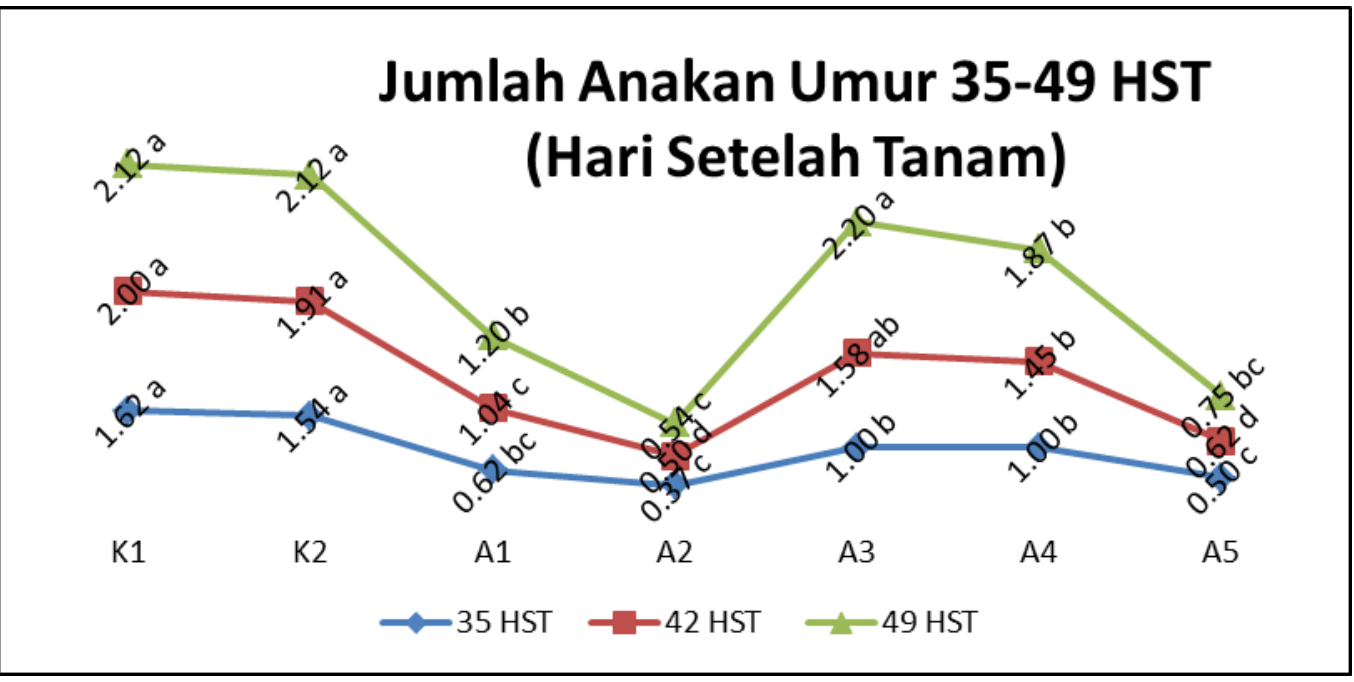

Gambar 3. Grafik uji lanjut DMRT jumlah anakan (batang) umur 35-49 HST.

Keterangan :

1.Angka-angka yang diikuti huruf berbeda menunjukkan berbeda nyata berdasarkan Uji Duncan Multiple Range Test (DMRT) pada taraf $\alpha 5 \%$ atau 0.05 .

2.K1 (Bokhasi kotoran domba 500 gram/ember), K2 (Bokashi Azolla sp. 400 gram/ember tanpa bokashi kotoran domba), A1 (Bokashi Azolla sp. 350 gram/ember + Bokbasi kotoran domba 500 gram/ember), A2 (Bokashi Azolla sp. 400 gram/ember + Bokhasi kotoran domba 500 gram/ember), A3 (Bokabsi Azolla sp. 450 gram/ember + Bokhasi kotoran domba 500 gram/ember), A4 (Bokashi Azolla sp. 500 gram/ember + Bokhasi kotoran domba 500 gram/ember) dan A5 (Bokashi Azolla sp. 550 gram/ember + Bokhasi kotoran domba 500 gram/ember).

Dari hasil uji lanjut Duncan Multiple Range Test (DMRT), bahwa rata-rata jumlah daun pada umur 35-49 HST bahwa perlakuan K2 dan K1 tidak berbeda nyata, diduga karena adanya ketersedian nitrogen $(\mathrm{N})$ yang tinggi meskipun memiliki konsentrasi dan perlakuan berbeda-beda. Nilai rata-rata jumlah anakan yang terbaik adalah K1, tetapi pada saat umur 49 HST perlakuan K2 memiliki nilai rata-rata yang sama yaitu 2.12 batang. Oleh karena itu, semakin unsur hara nitrogen $(\mathrm{N})$ yang tersedia dalam tanah berfungsi dalam merangsang munculna anakan dan sangat berperan penting (Matsuo, 1993). Selain daripada itu, Dalam MOL rebung bambu pun diduga adanya bakteri Azotobater sp. yang memiliki kandungan sitokinin dan giberelin. Sitokinin dan giberelin merupakan berfungsi untuk meningkatkan pembentukan jumlah anakan pada tanaman (Pavlista, et al.,2013 ; Niknejhad dan Pirdashti, 2012).
Perlakuan K2 dan K1 pada saat umur 35 HST berbeda nyata dengan perlakuan lainnya, diduga karena perlakuan A1-A5 bahwa kombinasi bokashi Azolla sp. dan bokashi kotoran domba terdapat zat asam organik terlalu terbanyak dianataranya asam suksinat, tartarat, sitrat glutaman, format, asetat propionate, laktonat dan tartarat dan oksalat. Selain daripada itu, Kandungan fosfat $(\mathrm{P})$ dan kalium $(\mathrm{K})$ organik tidak dapat langsung digunakan oleh tanaman karena perlu ditransformasi terlebih dahulu menjadi bentuk anorganik yang melalui proses mineralisasi dan dikatalis oleh enzim tanah fosfatase dan kalium. Dengan terlalu banyaknya zat asam tersebut maka pertumbuhan jumlah anakan lambat untuk berdiferensiasi. Nilai rata-rata pertumbuhan jumlah anakan yang paling rendah adalah A2. Namun, budidaya tanaman padi pandanwangi memiliki umur yang paling lama yaitu 155 hari sehingga untuk munculnya anakan 
pada saat umur 35-42 HST masih rendah (MP3C, 2015).

Pada umur 42 HST bahwa K2 dan K1 tidak berbeda nyata dengan A3 dan A4 diduga, karena zat asam organik berkurang tetapi unsur hara masih tersedia. Oleh karena itu, jumlah anakan tetap dipengaruhi oleh ketersediaan unsur hara semakin banyaknya bokashi diberikan maka nutrisi yang dibutuhkan tanaman semakin terpenuhi sehingga pertumbuhan anakan akan terpacu (Buntoro et al., 2014). Pada saat umur 49 HST bahwa K2 dan K1 tidak berbeda nyata dengan A3 diduga karena zat asam organik semakin berkurang dan pertumbuhan diferensiasi dan pemebelahan sel terjadi secara konstan serta unur hara masih tersedia. Selain ketersediaan unsur hara nitrogen $(\mathrm{N})$, bahwa peningkatan hara fosfat $(\mathrm{P})$ dapat meningkat meingkatkan pertumbuhan vegetatif diantaranya tinggi tanaman, jumlah anakan, jumlah daun dan indeks luas daun (ILD) (Syamsiah, 2008).

\section{Warna Daun}

Pada saat padi Pandanwangi berumur 21-49 HST, dari hasil uji ANOVA yang telah dilakukan bahwa warna daun memberikan hasil signifikan karena $\mathrm{P}$ value atau 0,008 (21 HST group warna daun 143), 0,004 (28 HST group warna daun 137), 0,001 (35 HST group warna daun 137), 0,000 (42 HST group warna daun 137) dan 0,000 (49 HST group warna daun 137) lebih kecil dari $\alpha$ 0.05 (Lampiran 6). Oleh karena itu, perlu dilakukan uji beda nyata dengan menggunakan uji lanjut DMRT.

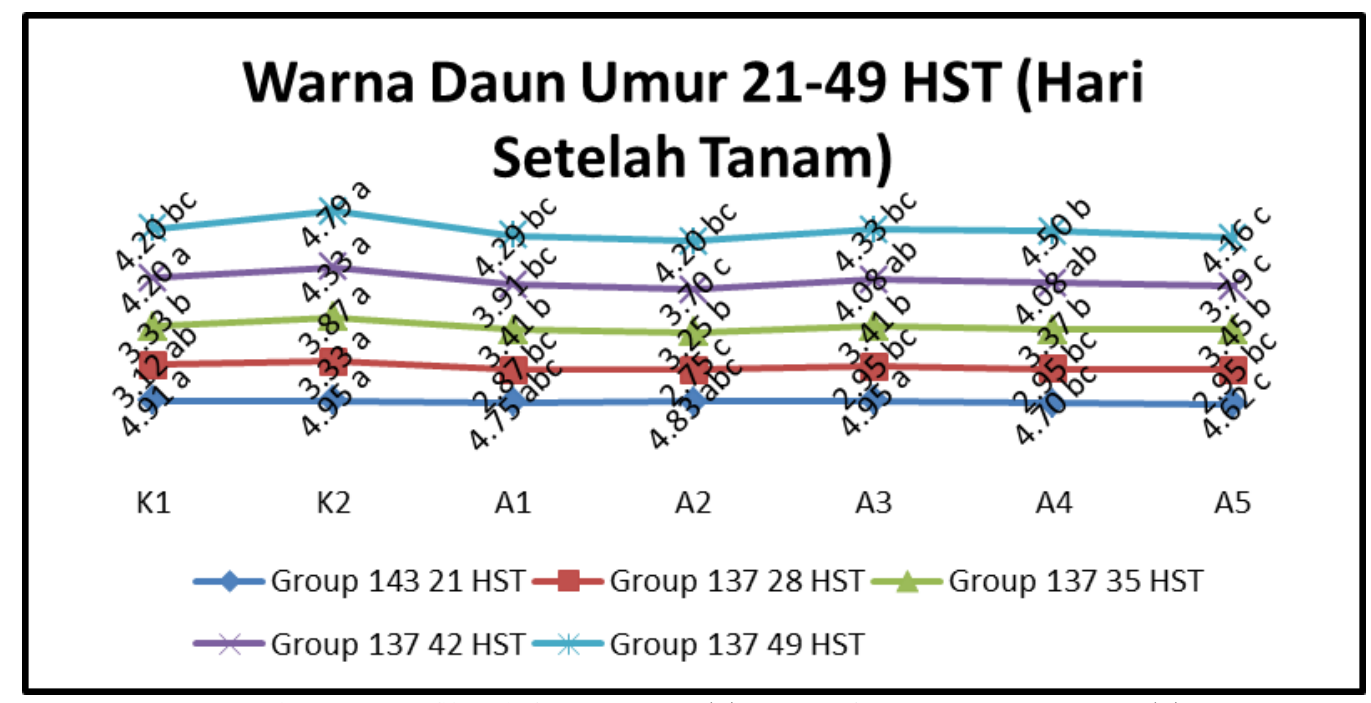

Gambar 4. Grafik uji lanjut DMRT warna daun umur 21-49 HST.

Keterangan :

1.Angka-angka yang diikuti huruf berbeda menunjukkan berbeda nyata berdasarkan Uji Duncan Multiple Range Test (DMRT) pada taraf $\alpha 5 \%$ atau 0.05 .

2.K1 (Bokhasi kotoran domba 500 gram/ember), K2 (Bokashi Azolla sp. 400 gram/ember tanpa bokashi kotoran domba), A1 (Bokashi Azolla sp. 350 gram/ember + Bokhasi kotoran domba 500 gram/ember), A2 (Bokashi Azolla sp. 400 gram/ember + Bokhasi kotoran domba 500 gram/ember), A3 (Bokahsi Azolla sp. 450 gram/ember + Bokhasi kotoran domba 500 gram/ember), A4 (Bokashi Aqolla sp. 500 gram/ember + Bokhasi kotoran domba 500 gram/ember) dan A5 (Bokashi Azolla sp. 550 gram/ember + Bokhasi kotoran domba 500 gram/ember).

Dari hasil uji lanjut Duncan Multiple Range Test (DMRT), bahwa rata-rata warna daun pada umur 21-49 HST adalah perlakuan $\mathrm{K} 2$ dan $\mathrm{K} 1$ tidak berbeda nyata karena dari kedua bokashi tersebut memiliki kandungan nitrogen $(\mathrm{N})$ yang tinggi yaitu K2 karena kandungan nitrogennya $(\mathrm{N})$ sangat tinggi yaitu 2,55$3,95 \%$ sedangkan $\mathrm{K} 1$ yaitu $0,65 \%$ sehingga berpengaruh terhadap warna daun (Akhda, 2009). Namun, perlakuan yang terbaik adalah K1. Nitrogen $(\mathrm{N})$
POTENSI BOKASHI Azolla sp. DENGAN BIOAKTIVATOR MOL REBUNG BAMBU TERHADAP PERTUMBUHAN PADI PANDANWANGI PADA FASE VEGETATIF 
berfungsi sebagai bahan penyusun asamasam amino, protein dan klorofil yang sangat penting dalam proses fotosintesis dan komponen penyusunan inti sel untuk menentukan kualitas dan kuantitas tanaman. Oleh karena itu, semakin banyaknya jumlah klorofil yang tersedia maka pigmen warna hijau semakin pekat dan hasil fotosintesis pun meningkat (Salisbury dan Ross, 1995).

Perlakuan K2 dan K1 pada saat umur 35 dan 49 HST berbeda nyata dengan perlakuan lainnya karena perlakuan A1-A5 mengalami pertambahan ukuran berlangsung secara konstan yang disebabkan oleh aktivitas meristem apikal (Mutia, 2013). Pada kandungan klorofil yang cukup maka dapat membentuk dan memacu pertumbuhan tanaman terutama pada fase vegetatif yaitu dengan merangsang pembentukan akar, batang dan daun terjadi dengan cepat sehingga ketersediaan makanan yang digunakan untuk proses organ vegetatif tersebut harus terpenuhi dalam keadaan jumlah yang banyak terutama nitrogen (N) (Marliani, 2011).

Pada saat umur 21, 28 dan 42 HST tidak berbeda nyata dengan perlakuan lainnya karena perlakuan A1-A5 diduga karena ketika bokashi Azolla sp. dan bokashi kotoran domba dikombinasikan maka pertumbuhan tanaman padi Pandanwangi sehingga pertumbuhan daun menjadi lambat dan warna daun pun tidak sempurna karena zat asam organik terlalu banyak yang dihasilkan oleh bakteri pelarut fosfat diantaranya asam suksinat, tartarat, sitrat glutaman, format, asetat propionate, laktonat, furmarete, tartarat dan oksalat karena pada saat fermentasi MOL rebung bambu, mikroorganisme beraktivitas mengeluarkan gas $\mathrm{CO}_{2}$ yang berdasarkan hasil dari pernapasan anaerob. Setelah itu, $\mathrm{CO}_{2}$ dilepaskan dengan membentuk senyawa asam karbonat $\left(\mathrm{H}_{2} \mathrm{CO}_{3}\right)$ yang mudah terurai menjadi ion-ion $\mathrm{H}^{+}$dan $\mathrm{CO}^{3-}$. Semakin lama waktu fermentasi maka dekomposisi bahan organik akan semakin lama dan $\mathrm{pH}$ menjadi rendah akibat peningkatan konsentrasi ion-ion $\mathrm{H}^{+}$sehingga akan menentukan keasaman MOL tersebut (Dwijoseputro, 2010).

Zat asam yang dihasilkan oleh bakteri tersebut, perlu ditransformasi terlebih dahulu menjadi bentuk anorganik yang melalui proses mineralisasi dan dikatalis oleh enzim tanah fosfatase dan kalium sehingga perkembangan skala warna daun pada saat masih muda umumnya rendah dan dapat meningkat dengan peningkatannya umur tanaman (Susila, 2015). Nitrogen merupakan salah satu unsur hara yang bersifat mobil dan apabila tanaman mengalami defisiensi terhadap nitrogen (N) maka akan berdampak terhadap daun dengan terjadi gejala klorosis dan kerdil (Herdiyanti, 2012). Warna daun merupakan suatu indikator untuk mengetahui kecukupan unsur hara nitrogen (N) pada tanaman. Nilai BWD dengan mencapai skala 4 menunjukkan titik kritis kecukupan unsur nitrogen (N) (Susila, 2015).

\section{PENUTUP}

\section{Kesimpulan}

1. Perlakuan K2 (Bokashi Azolla sp. 400 gram/ember tanpa bokashi kotoran domba) berpengaruh terhadap tinggi tanaman, jumlah daun, jumlah anakan dan warna daun.

2. Hasil nilai rata-rata $\mathrm{K} 2$ pada umur 49 HST pada tinggi tanaman yaitu 133.21 $\mathrm{cm}$, jumlah daun 16.37 helai, jumlah anakan 2.12 batang dan memiliki nilai sama dengan K2 (Bokashi kotoran domba 500 gram/ember), dan warna daun 4.79. Namun, jumlah anakan nilai rata-rata tertinggi terdapat pada A3 (Bokahsi Azolla sp. 450 gram/ember) yaitu 2.20 batang.

\section{DAFTAR PUSTAKA}

Amin, Muhammad. 2015. Pengaruh Umur Pindah Tanam Dan Jumlah Bibit Per Lubang Tanam Terhadap Pertumbuhan Tanaman Padi (Oryza sativa L.). Skripsi. Program Studi Agroteknologi. Fakultas Pertanian.
POTENSI BOKASHI Azolla sp. DENGAN BIOAKTIVATOR MOL REBUNG BAMBU TERHADAP PERTUMBUHAN PADI PANDANWANGI PADA FASE VEGETATIF 
Universitas Teuku Umar. Meulaboh-Aceh Barat.

Akhda, D.K.N. 2009. Pengaruh Dosis Dan Waktu Aplikasi Kompos Azolla sp. Terhadap Pertumbuhan Tanaman Bayam Merah (Alternanthera amoena Voss). Skripsi. Jurusan Bilogi. Fakultas Sains dan Teknologi Universitas Islam Negeri (UIN). Maulana Malik Ibrahim Malang.

Batara, Lily. N. 2015. Kualitas Mikroorganisme Lokal (MOL) Yang Digunakan Pada Penanaman Padi (Oryza Sativa L.) Dengan Metode System Of Rice Intensification (SRI) Organik. Tesis. Program Studi Bioteknologi Tanah dan Lingkungan. Sekolah Pascasarjana. Institut Pertanian Bogor. Bogor.

Buntoro, Bagus, H., Rogomulyo dan Trisnowati, Sri. 2014. Pengaruh Takaran Pupuk Kandang dan Intensitas Cahaya Terhadap Pertumbuhan dan Hasil Temu Putih (Curcuma zedoaria L.). Vegetalika. 4 (4):29-39.

Budiyanto, A.M.G dan Isnawan, B.H. 2014. Kajian Pemanfaatan Kompos Azolla pinnata Guna Mereduksi Dosis Pupuk Nitrogen Anorganik Pada Budidaya Sawi (Brassica juncea L.). Tesis. Program Studi Agroteknologi. Fakultas Pertanian. Muhammadiyah Yogyakarta. Yogyakarta.

Dewi, Intan R. 2008. Peranan dan Fungsi Fitohormon bagi Pertumbuhan Tanaman. Makalah. Fakultas Pertanian. Universitas Padjadjaran. Bandung.

Driyani, L.W. 2015. Pengaruh Pemberian Zat Pengatur Tumbuh (ZPT) Sintetik Auksin, Sitokinin Dan Giberelin Terhadap Kecepatan Pertumbuhan Tanaman Sawi Pakcoy (Brassica chinensis). Skripsi. Program Studi Pendidikan Biologi. Jurusan Pendidikan Matematika dan Ilmu Pengetahuan Alam. Fakultas Keguruan dan Ilmu
Pendidikan. Universitas Sanata Dharma. Yogyakarta.

Dwijoseputro D. 2010. Dasar-dasar Mikrobiologi. Jakarta :Djambatan.

Gunawan, Richard. 2011. Produksi Masal Inokulum Azotobacter, Azospirillum dan Bakteri Pelarut Fosfat dengan Menggunakan Media Alternatif. Skripsi. Program Studi Manajemen Sumberdaya Lahan. Departemen Ilmu Tanah dan Sumberdaya Lahan. Fakultas Pertanian. Institut Pertanian Bogor. Bogor.

Guntoro, W., Yessy, A.R dan Utomo, D.P. 2017. Peranan Plant Catalyst Dan Pupuk Kompos Terhadap Pertumbuhan Dan Hasil Tanaman Sawi (Brassica juncea). Agritrop Jurnal Ilmu-Ilmu Pertanian. 15 (2):59-65.

Hartanto, M. 2013. Budidaya Padi Organik Waktu Aplikasi Pupuk Kandang Dan Pemberian Pupuk Hayati. Skripsi. Departemen Agronomi dan Hortikultura. Fakultas Pertanian. Institut Pertanian Bogor. Bogor.

Herdiyanti, Tri. 2012. Pengurangan Dosis Pupuk Npk Pada Padi Sawah (Oryza sativa L.) Musim Tanam Keempat Di Karawang, Jawa Barat. Skrispi. Departemen Agronomi dan Hortikultura. Fakultas Pertanian. Institut Pertanian Bogor. Bogor.

Karjadi, A. K dan Buchory, A. 2007. Pengaruh Penambahan Auksin Dan Sitokinin Terhadap Pertumbuhan Tunas Bawang Putih. Jurnal. Hortikultura. 17(4):314-320.

Kementerian Pertanian. 2016. Komoditas Pertanian Sub Sektor Tanaman Pangan, Outlook Komoditas Pangan Padi. Jakarta:Kementerian Pertanian.

Khairunisa, 2015. Pengaruh Pemberian Pupuk Organik, Anorganik Dan Kombinasinya Terhadap Pertumbuhan Dan Hasil Sawi Hijau Brassica juncea L. Var. Kumala). Skripsi. Jurusan Biologi, Fakultas Sains dan Teknologi. Universitas Islam Negeri Maulana Malik Ibrahim. Malang.
POTENSI BOKASHI Azolla sp. DENGAN BIOAKTIVATOR MOL REBUNG BAMBU TERHADAP PERTUMBUHAN PADI PANDANWANGI PADA FASE VEGETATIF 
Kustiono, G., Indarwati dan Herawati, J. 2012. Kajian Aplikasi Kompos Azolla dan Pupuk Anorganik untuk Meningkatkan Hasil Padi Sawah (Oryza sativa L.). Seminar Nasional Kedaulatan Pangan dan Energi. Mojokerto, Juni 2012.

Lian B., Mo, PQ dan Liu, CQ. 2002. A Comprehensive Review Of The Mechanism Of Potassium Release By Silicate Bacteria. Acta Mineral Sinica. 22: 179-183.

Lie, FC., Yang, YZ dan Cheng, LJ. Advances In The Study Of Weathering Products Of Primary Silicate Minerals, Exemplified By Mica And Feldspar. Acta Petrol Mineral. 25: 440-448.

Liu, Wuxing., Xu, Xushi., Wu, Xianghua., Yang, Qiyin dan Lou, Yongming. 2006. Decomposition of silicate minerals by Bacillus mucilaginosus in liquid culture. Environmental Geochemistry and Health. 10 (28):133-140.

Manik, Agustiani Jojor, 2011. Pengaruh Zat Pengatur Tumbuh Difenokonazol Dan Ziram Terhadap Pertumbuhan Dan Produksi Padi Sawah (Oryza sativa L.). Skripsi. Departemen Agronomi Dan Hortikultura. Fakultas Pertanian. Institut Pertanian Bogor. Bogor.

Mardhiastuti, S., Suntoro dan Dewi, WS. 2015. Kajian Kualitas Formula Pupuk Organik Berbahan Dasar Kotoran Ternak Yang Diperkaya Bahan Mineral Dan Pengaya Mikroba. El-Vivo. 3 (1):41-53.

Marliani, Vitta, P. 2011. Analisis Kandungan Hara N Dan P Serta Klorofil Tebu Transgenik IPB 1 Yang Ditanam Di Kebun Percobaan PG Djatiroto, Jawa Timur. Skripsi. Program Studi Manajemen Sumberdaya Lahan. Departemen Ilmu Tanah dan Sumberdaya Lahan. Fakultas Pertanian. Institut Pertanian Bogor. Bogor.
Masyarakat Pelestari Padi Pandanwangi Cianjur (MP3C). 2015. Buku Persyaratan Permohonan Pendaftaran Indikasi Geografis Beras Pandanwangi Cianjur. Cianjur:MP3C.

Niknejhad, Yousof dan Pirdashti, Hemmatollah. 2012. Effect of Growth Stimulators on Yield and Yield Components of Rice (Oryza sativa L.) Ratoon. Journal of Applied and Basic Sciences. 3 (7):1417-1421.

Nurrahma, A.H.I. 2012. Pengaruh Jenis Pupuk Dan Dekomposer Terhadap Pertumbuhan Dan Produksi Padi Organik, Skripsi. Departemen Agronomi dan Hortikultura. Fakultas Pertanian. Institut Pertanian Bogor. Bogor.

Pavlista, Alexander, D., Santra, Dipak, K and Baltensperger, David, D. 2013. Bioassay of Winter Wheat for Gibberellic Acid Sensitivity. American Journal of Plant Sciences. 4 (10):2015-2022.

Rao, N.S.S. 1994. Mikroorganisme Tanah Dan Pertumbuban Tanaman. Edisi Kedua. Jakarta :Universitas Indonesia (UI-Press).

Rusco, E., Marechal, B., Tiberi, M., Bernacconi, C., CIabocco, G., Ricci, P. dan Spurio, E. 2009. Case Study-Italy Sustainable Agriculture and Soil Conservation (SoCo Project). JRC European Commission : Luxembourg.

Salisbury, F.B dan Ross, C.B. 1995. Fisiologi Tumbuban. Bandung:ITB Bandung.

Setyorini, Diah., Saraswati, Rasti dan Anwar, E.K. 2006. Pupuk Organik Dan Pupuk Hayati Organic Fertilizer And Biofertilizer. Badan Penelitian dan Pengembangan Pertanian:Bogor.

Sheng, XF., He LY. 2006. Solubilization of potassium bearing minerals by a wild type strain of Bacillus edaphicus and its mutants and increased potassium uptake by wheat. Can J Microbiol. 52 (1):66-72.

Simamora, J.A., Rauf, Abdul, Marpaung, Purba dan Jamilah. 2016. Perbaikan
POTENSI BOKASHI Azolla sp. DENGAN BIOAKTIVATOR MOL REBUNG BAMBU TERHADAP PERTUMBUHAN PADI PANDANWANGI PADA FASE VEGETATIF 
Sifat Kimia Tanah Sawah Akibat Pemberian Bahan Organik Pada Pertanaman Semangka (Citrullus Lanatus). Jurnal Agroteknologi. 4 (4): 2196-2201.

Suhastyo, A.A. 2011. Studi Mikrobiologi Dan Sifat Kimia Mikroorganisme Lokal (MOL) Yang Digunakan Pada Budidaya Padi Metode SRI (System of Rice Intensification). Tesis. Program Studi Ilmu Tanah. Sekolah Pascasarjana, Institut Pertanian Bogor. Bogor.

Susila, Sandi, O. 2015. Pengaruh Pemupukan Nitrogen (N) Dan Jarak Tanam Terhadap Pertumbuhan, Hasil Dan Kualitas Hasil Padi Japonica Varietas Hitomebore Di Daerah Tropik. Skripsi. Departemen Agronomi dan Hortikultura. Fakultas Pertanian. Institut Pertanian Bogor. Bogor.

Suwantoro, A.A. 2008. Analisis Pengembangan Pertanian Organik Di Kabupaten Magelang (Studi Kasus Di Kecamatan Sawangan). Tesis. Program Magister Ilmu Lingkungan. Program Pascasarjana. Universitas Diponegoro. Semarang. Syaifullah, Imam. 2016. Uji Efektifitas Bioaktivator Tanah Rayap Dan Makrofauna Uret Terhadap Aktivitas Dekomposisi Dan Kualitas Kompos Baglog. Skripsi. Program Studi Agroteknologi. Fakultas Pertanian. Universitas Muhammadiyah Yogyakarta. Yogyakarta.

Syam, Nurfajri. 2015. Pengaruh Pemberian Pupuk Hijau Cair Kihujan (Samanea saman) Dan Azolla (Azolla pinnata) Terhadap Kandungan NDF Dan ADF Pada Rumput Signal Brachiaria decumbens). Skripsi. Fakultas Peternakan. Universitas Hasanuddin. Makasar.

Syamsiyah, Syofiatin. 2008. Respon Tanaman Padi Gogo (Oryza sativa L.) Terhadap Stres Air Dan Inokulasi Mikoriza. Skripsi.
Program Studi Agronomi. Fakultas Pertanian. Institut Pertanian Bogor. Bogor.

Tamrin, Husni. 2005. Pengaruh Dosis Pupuk Urea Dan KCL Terhadap Jumlah Anakan Padi Varietas Pandanwangi (Oryza sativa L.). Skripsi. Program Studi Budidaya Pertanian. Fakultas Pertanian. Universitas Suryakancana. Cianjur.
POTENSI BOKASHI Azolla sp. DENGAN BIOAKTIVATOR MOL REBUNG BAMBU TERHADAP PERTUMBUHAN PADI PANDANWANGI PADA FASE VEGETATIF 
POTENSI BOKASHI Azolla sp. DENGAN BIOAKTIVATOR MOL REBUNG BAMBU TERHADAP PERTUMBUHAN PADI PANDANWANGI PADA FASE VEGETATIF
SITI YIYIS RAHMAH, ANGGA ADRIANA IMANSYAH, RIZA TRIHADITIA, R. TAUFIQ D. JATMIKA AHMAD NUR RIZAL 